\title{
Splenic artery aneurysm
}

\section{Aneurisma de artéria esplênica}

Rui Antônio Ferreira, TCBC-RJ'; Myriam Christina Lopes Ferreira²; Daniel Antônio lopes Ferreira, TCBC-RJ3; André Gustavo Lopes Ferreira ${ }^{4}$; Flávia Oliveira Ramos ${ }^{4}$.

\section{A B S T R A C T}

\begin{abstract}
Splenic artery aneurysms - the most common visceral artery aneurysms - are found most often in multiparous women and in patients with portal hypertension. Indications for treatment of splenic artery aneurysm or pseudoaneurysm include specific symptoms, female gender and childbearing age, presence of portal hypertension, planned liver transplantation, a pseudoaneurysm of any size, and an aneurysm with a diameter of more than $2.5 \mathrm{~cm}$. Historically, the treatment of splenic artery aneurysm has been surgical ligation of the splenic artery, ligation of the aneurysm, or aneurysmectomy with or without splenectomy, depending on the aneurysm location. There are other percutaneous interventional techniques. The authors present a case of a splenic artery aneurysm in a 51-year-old woman, detected incidentally.
\end{abstract}

Keywords: Aneurysm. Splenic Artery. Aneurysm, False.

\section{INTRODUCTION}

A neurysms of the visceral or splanchnic arteries are rare pathologies, but early recognition and treatment are essential, since approximately 25\% present with rupture in emergencies, resulting in a mortality of $8.5 \%$. The splenic artery aneurysms (SAA) are uncommon lesions that account for $60 \%$ of all visceral aneurysms ${ }^{1}$, with an estimated prevalence of $0.8 \%$ in the population. Generally asymptomatic, its incidence is four times higher in women than in men. Most aneurysms are small, less than $2 \mathrm{~cm}$ in diameter, saccular and located at the fork situated in the middle of the splenic artery or in its distal segment ${ }^{1,2}$.

\section{CASE REPORT}

A female, 51-year-old, single, white patient, native and resident of Rio de Janeiro, sought a private practice medical clinic with cervical lymphadenopathy of one month duration. Two years before, she had Hashimoto's disease that progressed to hypothyroidism requiring hormone replacement. There was also history of rheumatic fever, brucellosis, tonsillectomy and the presence of uterine fibroids. She denied surgery or abdominal trauma. Physical examination showed an increased lymph node, of hard consistency, adhered to deep planes, in the cervical region near the posterior edge of the left sternocleidomastoid. During the investigation of cervical lymphadenopathy we ordered several tests, including an abdominal ultrasound (US). It suggested the presence of a cystic lesion near the splenic hilum. We requested a magnetic resonance angiography of the abdominal aorta (Figures 1 and 2) to further study, which diagnosed a splenic artery aneurysm $2.5 \mathrm{~cm}$ in diameter. Once established the surgical indication, we proceeded to preoperative vaccination against Streptococcus pneumoniae and Haemophilus influenzae. The patient underwent splenectomy. The procedure, although started by laparoscopy, needed to be converted due to bleeding. The postoperative course was uneventful, the patient remaining asymptomatic.

\section{DISCUSSION}

Splenic artery aneurysms (SAA) are the most common type of arterial visceral aneurysms, accounting for $60 \%$ of all cases. The patient in question was female, consistent with the literature ${ }^{1-5}$, in which the prevalence of this pathological entity is 


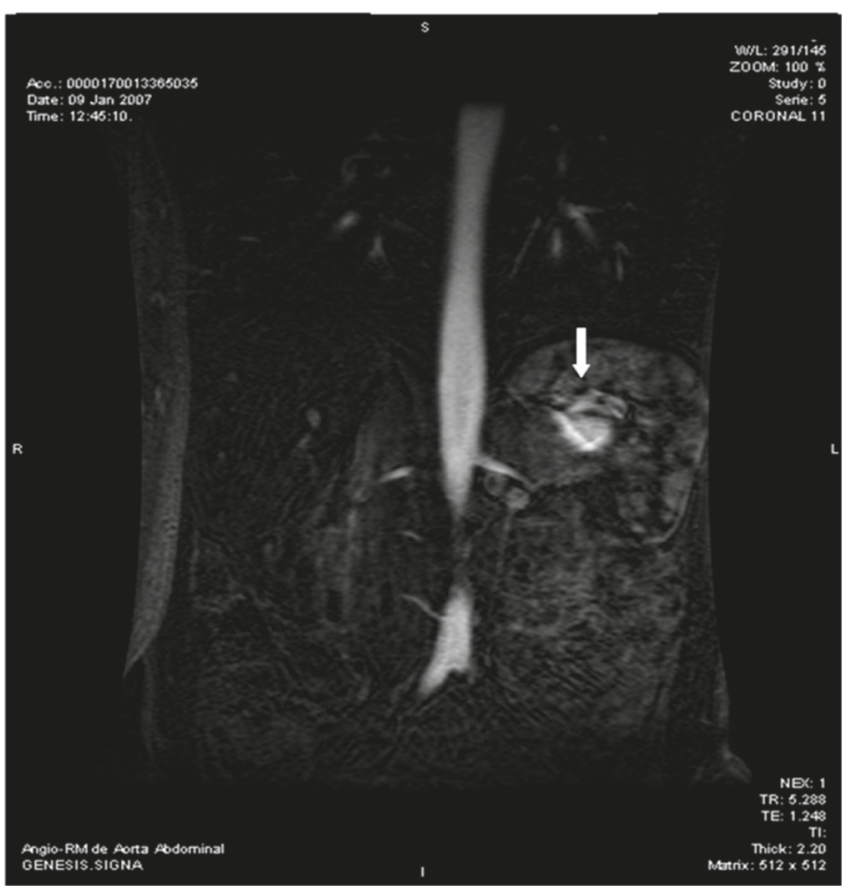

Figure 1. Angio-MRl image of the abdominal aorta, coronal section, showing the splenic artery aneurysm.

four times higher in this gender. Although the precise cause of the SAA has not been established, the most common pathologic finding is a defect of the tunica media, with loss of elastic fibers and smooth muscle ${ }^{3}$. Atherosclerosis - commonly observed in this disease - is probably more a post-aneurysm phenomenon than a primary cause of injury ${ }^{3,4}$. The increased blood flow in the splenic artery appears to be a relevant factor in its appearance, which is why these aneurysms are more frequently observed in patients with fibromuscular dysplasia, in portal hypertension, in infections, congenital anomalies, transplanted liver and even pancreatic carcinoma². Its higher prevalence in women, particularly multiparous, is explained by hormonal and hemodynamic changes typical of pregnancy that promote intimal hyperplasia of the vessel and subsequent fragmentation, facilitating the development of aneurysm. Another class of patients is one in which there are inflammatory changes of the arterial wall, as in polyarteritis nodosa, bacterial endocarditis or enzymatic digestion of the wall by a previous pancreatitis episode ${ }^{2}$.

The standard of the SAA is its asymptomatic nature at diagnosis, except in cases of rupture that, although being a rare event, is marked by bulky bleeding that occurs inside the peritoneal cavity, into some viscera (causing gastrointestinal bleeding) or into the pancreatic duct, a condition known as hemossucus pancreaticus ${ }^{2}$. Rupture is associated with high mortality rates $^{5}$. The patient in this case report was asymptomatic as for the aneurysm.

The absence of clinical signs and symptoms in most cases makes diagnosis difficult, and it is often done when performing routine tests ${ }^{3}$. A very suggestive finding of SAA - cystic lesion in the abdominal US should be further investigated with other imaging tests, differentiating it from other possible diagnostic hypotheses, such as pancreatic cystic tumor, pancreatic pseudocyst secondary to pancreatitis or, very rarely, a neuroendocrine tumor with this type of radiologic presentation ${ }^{2}$. In general, a computed tomography (CT) or a magnetic resonance angiography are sufficient to clarify the presence of a SAA, as was observed in this patient.

The SAA treatment indications include specific symptoms such as epigastric pain in the left upper quadrant and back, women of childbearing age,

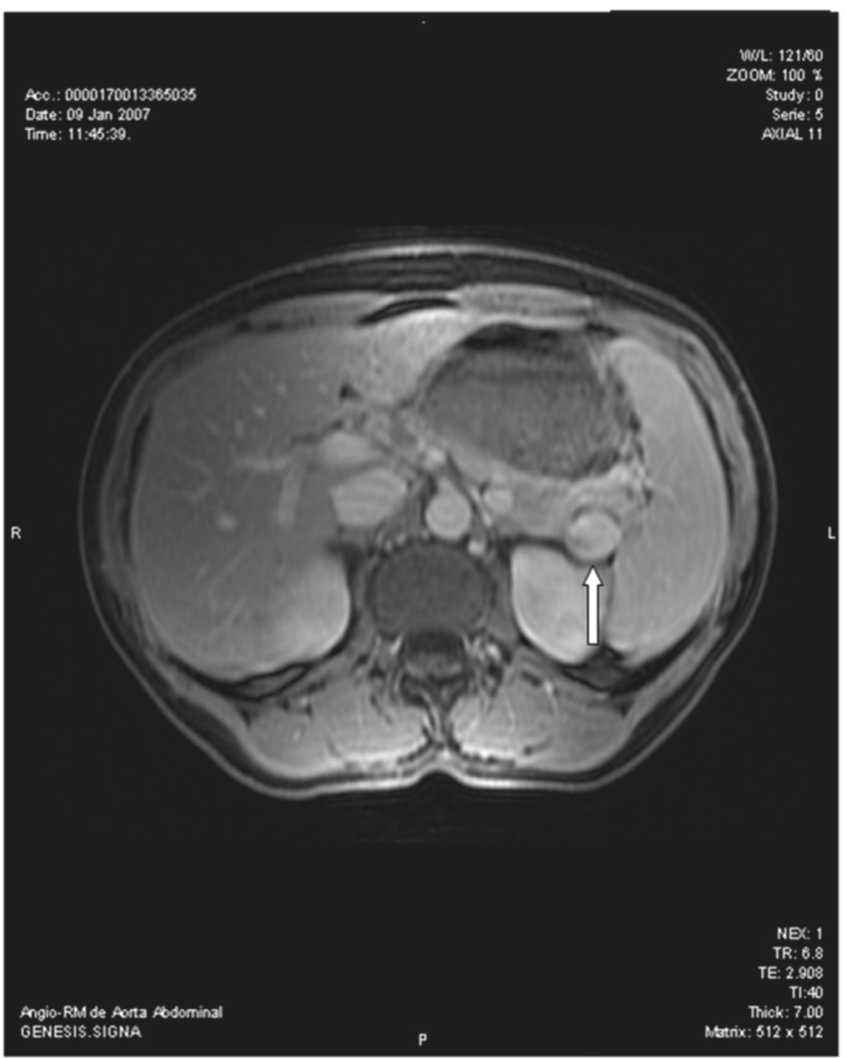

Figure 2. Image in axial section showing an aneurysm in the topography of the splenic artery. 
presence of portal hypertension, liver transplantation, pseudoaneurysms of any size and SAA with diameter greater than $2.5 \mathrm{~cm}$. In patients older than 60 years, follow-up CT scan every six months is advocated ${ }^{2}$. The greatest risk conditions comprise the SAA greater than $2 \mathrm{~cm}$, symptomatic and transplant patients, the SAA associated with inflammatory processes and those identified in women of childbearing age and pregnant women, the latter representing a great risk for both the mother and the fetus ${ }^{2}$.

Therapeutic alternatives are several, ranging from a simple vascular ligation (by open or laparoscopic route) to the need for splenectomy due to the proximity of the aneurysm with the spleen ${ }^{1}$. Endovascular procedures such as artery embolization or stent placement are also being used, minimizing the risks of surgery and shortening the patient's hospital stay ${ }^{1,3,5}$.

Postoperative complications are uncommon and were not observed in this case. Mortality is high in patients with an ongoing episode of pancreatitis.

The follow-up with CT or ultrasonography-Doppler to assess therapeutic efficacy should take place in subsequent months ${ }^{1}$.

\title{
R E S U M O
}

\begin{abstract}
Aneurismas da artéria esplênica - os aneurismas arteriais viscerais mais comuns - são encontrados mais frequentemente em mulheres multíparas e em pacientes com hipertensão portal. As indicações para o seu tratamento incluem sintomas específicos, sexo feminino e idade fértil, presença de hipertensão portal, paciente em fila de transplante hepático, um pseudoaneurisma de qualquer tamanho, e um aneurisma com um diâmetro superior a 2,5cm. Historicamente, o tratamento do aneurisma da artéria esplênica tem sido a ligadura cirúrgica da artéria esplênica, a ligadura do aneurisma ou a aneurismectomia, com ou sem esplenectomia, dependendo do local do aneurisma. Existem outras técnicas intervencionistas percutâneas. Os autores apresentam o caso de um aneurisma de artéria esplênica em uma mulher de 51 anos de idade, diagnosticado incidentalmente.
\end{abstract}

Descritores: Aneurisma. Artéria Esplênica. Falso Aneurisma.

\section{REFERENCES}

1. Madoff DC, Denys A, Wallace MJ, Murthy R, Gupta S, Pillsbury EP, et al. Splenic arterial interventions: anatomy, indications, technical considerations, and potential complications. Radiographics. 2005;25 Suppl 1:S191-211.

2. Larraín D, Fava M, Espinoza R. Splenic artery aneurysm: case report. Rev Med Chil. 2005; 133(8):943-6.

3. Kenningham R, Hershman MJ, McWilliams RG, Campbell F. Incidental splenic artery aneurysm. J R Soc Med. 2002;95(9):460-1.

4. Dorman BA, Carney WI. Aneurysm of the splenic artery. Dis Chest. 1965;48:78-82.

5. Greene DR, Gorey TF, Tanner WA, Lane BE, Collins $P G$. The diagnosis and management of splenic artery aneurysms. J R Soc Med. 1988;81(7):387-8.

Received in: 11/02/2016

Accepted for publication: 01/05/2016

Conflict of interest: none.

Source of funding: none.

\section{Mailing address:}

André Gustavo Lopes Ferreira

E-mail: andrelopes_uff@yahoo.com.br 